\title{
Periodic Inspections of Residential Heating Appliances for Solid Fuels: Review of Legal Regulations in Selected European Countries
}

\author{
Katarzyna Rychlewska ${ }^{1 *}$, Jolanta Telenga-Kopyczyńska', Rafał Bigda', Jacek Żeliński \\ 1 Institute for Chemical Processing of Coal, ul. Zamkowa 1, 41-803 Zabrze, Poland \\ *Corresponding author's e-mail: krychlewska@ichpw.pl
}

\begin{abstract}
The article presents the legal framework of periodic control systems of individual heating devices in the Federal Republic of Germany, the Czech Republic and Switzerland. The scope of periodic inspections carried out in considered countries, the persons responsible for performing them, the method of data acquisition and administrative bodies responsible for supervising the fulfillment of the obligation, as well as the sanctions for law violations related to small heat sources operation in the residential sector were discussed.
\end{abstract}

Keywords: emission from residential sector, solid fuel boilers, solid fuel space heaters, legal regulations

\section{INTRODUCTION}

The housing and communal sector has been mentioned for many years as the main source of air pollutant emissions, such as suspended particular matter $\left(\mathrm{PM}_{10}\right.$ and $\left.\mathrm{PM}_{2.5}\right)$ and polycyclic aromatic hydrocarbons (PAH) [NCEM, 2019; EEA, 2019]. The actions taken to reduce the emissions from individual heating devices concern, inter alia, the legal regulations on the quality and type of fuels allowed to use, local bans on the continuous or periodic combustion of solid fuels, as well as the possibility of bringing to the market the devices that meet certain emission standards, as well as the technical condition control system and compliance with the introduced standards during the operation of heating devices by citizens [DU, 2016; DEC, 2016; WHO, 2015; Amann, 2018; GRAE, 2010]. Appropriate legal solutions have been introduced in the European countries to create a legal framework for systems of more or less comprehensive control of individual heating devices, both boilers and local space heaters [GRAE, 2010]. As a result of regular control activities performed, it is possible to identify the heat sources the operation of which violates the law and, therefore, to take much more effective corrective actions in real time corresponding to specific cases. Regular inspections of individual heating devices allow the identification of furnaces which, due to their age or long-term improper operation, may be in poor technical condition. In addition, it is possible to identify the cases where exceeding the emission standards is due to improper operation of often a new device, which can be eliminated through training in the scope of regulation and good combustion practice conducted by the inspector.

The article presents the method of organizing periodic control systems for individual heating devices in the Federal Republic of Germany, the Czech Republic and Switzerland. The scope of periodic inspections carried out in individual countries, the persons authorized to carry them out and the method of data acquisition were discussed. In addition, the entities responsible for the supervision of compliance with the control obligation and the sanctions for violating the law on the operation of small heat sources in the household and municipal sector were characterized.

\section{GERMANY}

In Germany, the operation of individual heating devices, including boilers and solid fuel local 
space heaters, is regulated directly by two legal acts: the $1 . B I m S c h V$ Regulation on the operation of small and medium-sized fuel combustion plants not requiring a permit [1.BImSchV, 2010] and the KÜO Regulation on cleaning and control of the flue gas discharge system [KÜO, 2009].

Inspection of small heat sources pursuant to the regulations of $1 . \mathrm{BImSchV}$ and $\mathrm{KÜO}$ is carried out by persons holding a chimney sweep diploma, whose duties and powers are regulated by the SchfHwG artisan's chimney law [SchfHwG, 2008]. The maximum rates for the inspection are calculated, depending on its scope, in accordance with KÜO guidelines.

In contrast to the solutions applicable, among others in Poland and the Czech Republic, in Germany, the possibility of operating a heating boiler depends on the actual concentrations of pollutants measured in operating conditions (Table 1), instead meeting the requirements specified in the indicated normative documents/ directives, confirmed by the tests carried out by an accredited laboratory at a measuring setup during the time of bringing the device to the market. Moreover, both in relation to the regulations in their original wording, which allow dust concentration equal to $150 \mathrm{mg} / \mathrm{m}^{3}$ [GEA, 2017], and the Ecodesign Directive in force from January 2020 , the emission limit values for boilers installed from 2015, specified in 1 . BImSchV, are very stringent and may not exceed $20 \mathrm{mg} / \mathrm{m}^{3}$ under actual operation conditions. It should also be noted that, irrespective of the regulations of the Ecodesign Directive for solid fuel boilers, the authorities of the Federal Republic of Germany have asked the European Commission not to alleviate the emission standards in force so far [Notification, 2020], arguing that maintaining more stringent dust emission limits is justified by important reasons specified in Article 36 of the Treaty on the Functioning of the European
Union (TFEU), in particular the protection of human health and the environment.

In the Federal Republic of Germany, individual solid fuel heating devices with a power of 4 to $500 \mathrm{~kW}$ are covered by the system of preliminary and periodic controls, which should be carried out once every two calendar years. The provisions of Article 14 of the Regulation 1.BImSchV oblige the users of boilers and local space heaters to notify the regional chimney sweep master about the installation of a new heating device or a significant modification of the operating device in order to adapt it to the requirements after the expiry of the transitional deadlines. The initial inspection should be carried out by an authorized chimney sweep up to 4 weeks after installing or modifying the heating device.

In order to confirm that the heating device meets the requirements for the pollutant emission limits, during the initial inspection, the controller also measures the pollutant emission in accordance with the methodology presented in the VDI-4207-2 procedure [VDI 4207-2, 2016]. In the case of local space heaters, which are not subject to periodic measurements of the concentration of the pollutants emitted, confirmation of compliance with the requirements set out in 1 . BImSchV takes place only once, during the initial inspection. The user of the device is obliged to either present to the inspecting person the documentation issued by the manufacturer for a specific device confirming that it meets the requirements set out in Regulation 1.BImSchV in terms of the limit values of carbon monoxide and dust emissions, or, in the absence of a relevant document, an order to a chimney sweep with additional qualifications to measure pollutant emissions at the place where the device is used.

According to Article 4 (8) of 1.BImSchV, the user of both an individual heat source with manual feeding of solid fuel and a local space heater,

Table 1. Emission Limit Values (ELV) for boilers firing solid fuels under operating conditions according to Article 5 (1) of 1. BImSchV

\begin{tabular}{|c|c|c|c|}
\hline \multirow{2}{*}{ Fuel } & \multirow{2}{*}{$\begin{array}{l}\text { Nominal thermal power, } \\
\text { kW }\end{array}$} & \multicolumn{2}{|c|}{$\mathrm{ELV}, 13 \% \mathrm{O}_{2}$} \\
\hline & & Dust, $\mathrm{mg} / \mathrm{m}^{3}$ & $\mathrm{CO}, \mathrm{mg} / \mathrm{m}^{3}$ \\
\hline $\begin{array}{l}\text { Hard coal, lignite, peat, charcoal, raw lump wood and } \\
\text { chips, straw and other crop residues; briquettes, pellets } \\
\text { and other forms of raw wood (DIN 51731). }\end{array}$ & $\geq 4$ & 20 & 400 \\
\hline \multirow{2}{*}{$\begin{array}{l}\text { Painted, coated and impregnated wood and its waste; } \\
\text { plywood, chipboards, fibreboards and long-lasting } \\
\text { non-impregnated wood. The coatings must not contain } \\
\text { heavy metals. }\end{array}$} & $\geq 50-500$ & 20 & 400 \\
\hline & $>500$ & 20 & 300 \\
\hline Straw and similar crop residues & $\geq 4-100$ & 20 & 400 \\
\hline
\end{tabular}


during the initial inspection is obliged to consult a chimney sweep on the proper use of the installation, including the basics of the solid fuel combustion process and its individual phases, proper fuel storage and solid fuel handling details no later than one year after installation.

\section{Scope of control}

According to the regulations being in force in Germany, the scope of periodic inspections of solid fuel boilers with a rated heat output of up to $500 \mathrm{~kW}$ and local space heaters includes:

- assessment of the technical condition of the device: inspection of the technical condition of the installation should be carried out in accordance with the device's manual. The identified technical deficiencies that may significantly affect the operation of an individual heating device and the results of emission measurements for boilers (e.g. leaks, material defects, corrosion of components) should be eliminated.

- control of combusted fuel and the method of its storage: during the periodic inspection of the solid fuel boiler, the controller checks whether the fuel complies with the requirements specified in Paragraph 3 (1) of 1.BImSchV and whether it complies with the instructions provided by the manufacturer of the heating device based on the documents in the possession of the owner containing the information on the quality parameters of the fuel and the data on the packaging. The inspector visually assesses the fuel assortment, the shape of its individual pieces, the presence of outside material and performs the measurement of the moisture content in the case of lump wood. The method of fuel storage is also controlled.

- inspection of the measuring hole and measurement of the concentration of total dust and carbon monoxide in the flue gas in the case of solid fuel boilers.

\section{Measurements methodology}

For the purposes of periodic inspections carried out by chimney sweeps, the VDI 4207-2 procedure has been developed, which contains the guidelines for the inspection of individual solid fuel heating devices under actual operating conditions.
The measurement procedure differs depending both on the fuel supply method and the method of air supply to the combustion chamber. Nevertheless, irrespective of the type of device and the changes in the load of the heater [1.BImSchV, 2010; VDI 4207-2, 2016] related to the measurement method, the sampling of the exhaust gas must start 5 minutes after adding fuel according to the procedure and always be carried out for 15 minutes. The concentration of total dust and carbon monoxide is defined as the average value from a 15-minute measurement. At the same time, it is required to measure the oxygen content in the exhaust gas. The emission limit value is considered to be complied with, if the measured value, minus the measurement uncertainty specified for the measuring device, and converted to a reference oxygen content of 13 vol.\% does not exceed the emission limit values defined for the type of heating device in Regulation 1.BImSchV.

\section{Control protocol}

The reports from the measurements carried out by chimney sweeps are provided within 14 days of the inspection to the district chimney sweep master. Once a calendar year, the district chimney sweeper reports the measurement results to the guild association responsible for the federal state. For each calendar year, the national chimney sweep guilds compile lists of the measurement results and submit them to the highest anti-emission protection office in the respective federal state or to the competent state authority within the meaning of federal state law. For each calendar year, a nationwide statement is produced and submitted to the Federal Ministry for the Environment, Nature Conservation and Nuclear Safety.

\section{Offenses and Sanctions}

In the event of a negative result of the inspection, the user of the heating device is given a specified period of time (4-6 weeks) to bring the system into operation. In the event of a negative result of the re-inspection, the chimney sweep issues an appropriate report and the heating device is sealed and cannot be used any further.

The offenses listed in Paragraph 24 of Regulation $1 . \mathrm{BImSchV}$ are punishable according to Paragraph 62 (1) pt. 7 of the Federal Emission Protection Act [BImSchG, 1975], which states that anyone who intentionally or negligently 
violates any regulations issued under Paragraph 23 (1) of BImSchG is liable to a fine of up to 50,000 euros.

\section{CZECH REPUBLIC}

The issues related to the protection of air against pollution related to the operation of small heat sources using solid fuels are regulated at the national level by Act 201/2012 Sb. Air Protection Law of April 2, 2012, as amended [Zákon č. 201/2012, 2012] and the Regulation of the Czech Minister of the Environment 415/2012 Sb, which defines the template of a report on periodic inspection, the quality requirements for the solid fuels burnt in heating devices with a rated power of 10 to $300 \mathrm{~kW}$ and the reference rates for periodic inspections [Vyhláška č. 415/2012, 2012]. The obligations of equipment owners and provisions regulating the issues related to the operation of heat sources in the household and municipal sector are summarized in the Communication by of the Czech Minister of the Environment from February 2, 2019 on the operation and control of stationary combustion sources with a rated heat output of $300 \mathrm{~kW}$ or lower [Sdělení, 2019].

Pursuant to Paragraph 17 (1) lit. h) of the Czech Air Protection Act, each user of a solid fuel combustion installation with a rated heat output of 10 to $300 \mathrm{~kW}$ is obliged to ensure the sound technical condition of the equipment in use and the compliance of the operating method of this source controlled with the instructions provided by the manufacturer every two calendar years.

Inspection of the technical condition and operation of a solid fuel heat source in the territory of the Czech Republic is carried out by a qualified heating engineer or service technician trained by the manufacturer of the heat source, who is also authorized to install, operate, maintain and inspect the above-mentioned devices. The contact details of the person authorized for statutory inspection can be obtained directly from the manufacturer/distributor of the heating device or in the database of qualified persons (Article 17a of the Air Protection Act).

\section{Scope of control}

According to the regulations being in force in the Czech Republic, during periodic inspections of the technical condition and operation of boilers and local space heaters, the person authorized to perform the inspection should pay attention to the following aspects:

- connection to a hot water central heating system for economical heat production and distribution;

- equipping the device with a heat accumulator, if such necessity has been indicated by the manufacturer in order to achieve the declared parameters of thermal efficiency and emissions;

- equipping the heat source with a mixing valve installed to maintain the temperature of water returning to the boiler as indicated by the manufacturer and to control the outlet temperature of the heating water;

- quality of connection of the combustion source with the chimney flue in order to achieve the desired chimney draft in accordance with the applicable regulations and the manufacturer's instructions for a stationary combustion source;

- technical condition of the outer casing of the heating device, combustion chamber, burner, flaps, inlet and cleaning flues, channels for supplying air for combustion and fuel, including the feeder and supply pipe, sensor settings for controlling the heating device and cooperation of the regulator with control elements;

- in addition, the inspection report should contain the information on whether the heat source meets the minimum emission requirements specified in Annex 11 to the Air Protection Act. The operator of the device must ensure, in accordance with Article 41 (16) of the Air Protection Law that the device operated meets the minimum emission requirements by September 1, 2022 at the latest;

- the fuel burned - pursuant to Paragraph 17 (1) lit. c) of the Air Protection Act - only the fuels with the quality parameters specified in Annex 3 to Regulation 415/2012 and only the fuels indicated by the manufacturer of the individual heating source in the operating instructions may be burned in the heating devices covered by the regulations;

- fuel storage, which should ensure its quality parameters, especially in terms of its moisture content;

- compliance of the operation of an individual heating device with the operating instructions of the producer of this source, in particular the timeliness of the maintenance activities. 
The person authorized to carry out the inspection should train the owner/user of the device in the proper operation of the combustion source in order to achieve optimal working conditions and minimize its impact on the environment. On the basis of the information in the inspection report, the owners/users of heating devices may be obliged to introduce the indicated remedial/corrective measures, if it turns out that they violate the obligations specified in the Air Protection Act. At the same time, a time limit must be set for the implementation of corrective measures. The time for implementation of remedial measures is not regulated by law; however, it must be as short as possible and at the same time realistic in terms of implementing the necessary measures.

\section{Control protocol}

The template of the report from the conducted control is an attachment to Regulation $415 / 2012 \mathrm{Sb}$. At the request of the commune office, owner of a boiler is obliged to present a document confirming the fulfilment of the obligation. In addition, from January 1, 2020, the inspector is obliged to report to the Ministry of the Environment, via the integrated reporting system (ISPOP), the data from the inspections carried out in the scope specified in Annex 18 to Regulation $415 / 2012 \mathrm{Sb}$, no later than 60 days from the date of issuing the report from the control of the combustion source of solid fuels.

\section{Offenses and Sanctions}

The offenses against the environment that may be committed by natural persons, as well as the penalties are specified in Art. 22 sec. 1 and 2 of the Air Protection Act. If the inspection is not carried out or documents are not delivered to the Municipal Office at its request, the owner is liable to a fine of up to CZK 20,000. Moreover, if the owner does not take the remedial measures specified by the municipal authorities within the prescribed period, the municipal authorities with extended powers are entitled to issue a decision to stop the operation of the heat source (Article 22 (1)).

\section{SWITZERLAND}

The issues related to the operation of i.a. small combustion plants of solid fuels, including fuel requirements, frequency and scope of statutory measurements to which individual heating devices are subject are regulated by the provisions of the Clean Air Regulation (LVR) [LVR, 1985] and local legal acts enacted by the cantonal authorities. As in the case of German regulations, in accordance with Article 12 (1) of the LVR, any person who operates or wants to start operating an air polluting plant is required to report this to the cantonal/municipal authorities. The control of compliance with the provisions on air protection is, as in Poland, the responsibility of the authorities of local government units - pursuant to the provisions of Article 13 (1) the authorities of cantons/municipalities may carry out control activities using their own human resources or entrust them to the persons with minimum competences indicated by the Swiss Federal Office for Environment [AWEL, 2019; BU, 2018]. The analysis of cantonal legal acts shows that control activities are entrusted i. a. to chimney sweeps (Canton Zurich) or fire inspectors (Canton Graubunden). The contact details for the inspectors operating in selected areas of cantons are published on the websites of cantonal environmental protection departments [AWEL, 2019; BU, 2018].

There are three models for the control of individual heating devices in the Swiss cantons. According to the analyzed documents/information published by the authorities of the Swiss cantons, the choice of the model is left to the authority of the municipalities. Moreover, it is also possible for a municipality within a given canton to develop its own control model. Moreover, the analysis of local legal acts adopted in the analyzed cantons shows that the inspections of individual solid fuel heating devices are carried out every two, but not four years, as it results from the provisions of the LVR. Moreover, the LVR does not explicitly define either the scope of the conducted inspections or the measurement methodology, referring to the documents prepared by the Swiss Federal Office for Environment (BAFU) and to cantonal documents. The provisions in force in Switzerland are therefore also similar in this matter to the Polish legislation, which does not establish the national guidelines for the organization of environmental compliance control systems, giving a lot of freedom to environmental protection authorities at the local government level. 
Under the provisions of Article 13 (3) the controls should be repeated at least:

- every four years for boilers with a nominal heat output of up to $70 \mathrm{~kW}$ fired with raw lump wood (including wood with bark, chopped firewood, wood briquettes, brushwood and cones, and solid wood cuttings produced exclusively by mechanical processing), raw wood other than lumpy (in particular pellets, sawdust, shavings, sanding dust or bark), waste wood such as fence posts, bean stakes and other solid wood items used in horticulture or agriculture.

- every two years for other fuel combustion installations.

The requirements for the heating devices brought to the market in Switzerland are regulated by the Regulation on the energy efficiency requirements for series-produced systems, vehicles and equipment of November 1, 2017, as amended [EnEV, 2017], which introduces requirements of the Ecodesign Directive for both boilers and local space heaters into Swiss legislation. Nevertheless, irrespective of the requirements for the products brought to the market, the emission standards for carbon monoxide and dust for users of heating devices with a rated thermal power of up to $70 \mathrm{~kW}$ under real operating conditions have also been introduced in Switzerland (Table 2).

\section{Scope of control}

As in the case of the Federal Republic of Germany, the heating devices in Switzerland are subject to an acceptance test. The first measurement/control (pre/acceptance measurement) must be performed within three months, but no later than twelve months after the commissioning of a new or upgraded installation (Article 13 (2) of LVR). The dust emission measurement is carried

Table 2. Emission limit values (ELV) for appliances firing solid fuels under operating conditions according to Annex 3 of LVR

\begin{tabular}{|l|c|c|}
\hline \multirow{2}{*}{\multicolumn{1}{|c|}{ Device }} & \multicolumn{2}{c|}{$\mathrm{ELV}, 13 \% \mathrm{O}_{2}$} \\
\cline { 2 - 3 } & $\begin{array}{c}\mathrm{CO} \\
\left(\mathrm{mg} / \mathrm{m}^{3}\right)\end{array}$ & $\begin{array}{c}\text { Dust } \\
\left(\mathrm{mg} / \mathrm{m}^{3}\right)\end{array}$ \\
\hline Kitchen stoves & 4000 & 100 \\
\hline Local space heaters & 2500 & 100 \\
\hline Boilers with manual fuel loading & 2500 & 100 \\
\hline Boilers with automatic fuel loading & 1000 & 50 \\
\hline
\end{tabular}

out only in the case of acceptance controls and in cases of reports of excessive smoking from the household. For wood-fired boilers with a heat output greater than $70 \mathrm{~kW}$ or fired with residual wood, the concentrations of both pollutants in the flue gas shall be controlled every two years.

As with the provisions of the German Regulation 1.BImSchV, no periodic emission measurements are performed in Switzerland for local space heaters. However, if a device of this type is used regularly (wood consumption over $1 \mathrm{~m}^{3}$ per year), a visual inspection is carried out every two years. This makes it possible to control if the local heater is technically efficient and if it is fired with a suitable fuel. In order to reduce the emissions from individual heating devices, users are trained in the basics of the combustion process.

Mass produced local space heaters using biogenic solid fuels according to point 524 (1) of Annex 3 to the LVR, are exempt from the emission measurement during the acceptance control, provided that a declaration of performance or an equivalent manufacturer's declaration is presented in accordance with Article 20e of LVR. On the other hand, space heaters built by stove fitters are exempt from the above-mentioned measurement if they:

- have been designed according to a recognized calculation procedure, in particular the Feusuisse association calculation program for tiled stoves;

- are equipped with dust reduction devices that comply with the best available technology, in particular with the requirements of the technical procedure VDI 3670 - Waste gas cleaning. Downstream dust control devices for smallsized solid fuel combustion systems.

Historical stoves up to $0.4 \mathrm{~m}^{3}$ and kitchen stoves manufactured by craftsmen are also exempt from the acceptance measurement if they have been built in accordance with the recognized principles of combustion technology or are equipped with a dust reduction system that meets the requirements of VDI 3670.

In the case of the boilers with a nominal heat output of up to $70 \mathrm{~kW}$, which are powered by solid biofuels (except for the boilers in which painted, coated, glued wood is burned and the resulting waste from the wood industry, excluding wood pressure impregnated with wood preservatives or protected with coatings) containing halogenated organic compounds and disposable solid wood 
pallets), the dust measurement is not performed during periodic inspections.

In turn, in accordance with point 22 of Annex 3 to the LVR, periodic measurements of carbon monoxide emissions do not apply to combustion sources of solid fuels, such as:

- installations operating less than 100 hours a year;

- heating appliances with a rated heat output below $12 \mathrm{~kW}$ used for heating individual rooms;

- coal-fired local space heaters;

- local space heaters for biogenic solid fuels, provided that they are fired with raw lump wood (including wood with bark, cut firewood, wood briquettes, brushwood and cones and solid wood cuttings produced exclusively by mechanical processing), raw wood and other than lumpy (in particular pellets, sawdust, shavings, sanding dust or bark), waste wood such as fence posts, bean stakes and other solid wood objects used in horticulture or agriculture.

For local space heaters that are not subject to regular emission measurements, the ash from the combustion of solid fuels and the technical condition of the installation are primarily checked during the periodic visual inspection. During the first such inspection, the person authorized to carry it out trains the user/owner in the proper use of the heat source and the way of handling and storing solid fuels.

\section{Measurement methodology}

The measurements of emissions under operating conditions in the Swiss cantons should be carried out in accordance with the guidelines for measuring the emissions from oil, gas and wood heating appliances developed by the Federal Office for the Environment (BAFU) [BU, 2018]. The user of an installation that is required to carry out periodic emission measurements is required to make a test borehole that meets the requirements specified in the BAFU guidelines. The measurement procedure with respect to the start time of the measurement after fuel addition and the gas sampling time vary depending on the type of device and the method of fuel delivery.

The individual measurement involves determining the concentration of carbon monoxide, dust concentration, oxygen content in the exhaust gas, optionally carbon dioxide and the exhaust gas temperature.

\section{Control protocol}

The LVR does not establish a template for an inspection report. Due to the lack of a uniform model sanctioned at the level of national legislation, each of the cantons lays down requirements regarding the data catalogue that must be included in the report on the inspection of an individual heating device.

\section{RECAPITULATION}

The conducted analysis of the legal documents regulating the functioning of periodic control systems for individual solid fuel heating devices showed fundamental differences in the analyzed European countries, both in terms of the organization of the system and the role of individual authorities in its operation, as well as the scope of control. A brief summary of the identified differences is provided in Table 3.

Comprehensive measurement of the pollutant concentration in the exhaust gas, including both dust and carbon monoxide, is carried out only in Germany, where the actual emission of pollutants under operating conditions determines the possibility of operation. The legal solution adopted in Switzerland covers only the control of the concentration of carbon monoxide, ordering the measurement of dust only in the cases when excessive smoke from the chimney is observed. An important element of the German and Swiss systems is the need to notify the installation or replacement of the heating device and the acceptance control, which allows for the verification of the actual emission of pollutants at an early stage of the device's operation and the quick introduction of appropriate modifications reducing the negative impact of the heat source on air quality. The obligation to notify also allows the supervisory authorities to obtain complete and current inventory of the solid fuel devices operated in their areas and to implement the measures to reduce "low emissions" more effectively. In addition, in the case of all analyzed systems, the quality of the burned fuel is also controlled, which, apart from meeting the quality requirements introduced by national regulations, should primarily meet the quality parameters indicated by the manufacturer for which the declared emissions have been achieved. Attention is also drawn to the fact that legal regulations in the analyzed countries 
Table 3. Comparison of organization and scope of analyzed periodic inspection systems

\begin{tabular}{|c|c|c|c|}
\hline Control system & Germany & Czech Republic & Switzerland \\
\hline $\begin{array}{l}\text { Persons authorized to carry out the } \\
\text { inspection }\end{array}$ & Chimney sweep & $\begin{array}{l}\text { Heating equipment service } \\
\text { trained by manufacturers }\end{array}$ & $\begin{array}{c}\text { Persons with appropriate } \\
\text { certificates indicated by BAFU }\end{array}$ \\
\hline $\begin{array}{l}\text { Application for purchase / } \\
\text { replacement / retrofitting of the } \\
\text { device }\end{array}$ & Yes & No & Yes \\
\hline $\begin{array}{l}\text { Direct supervision over the } \\
\text { fulfillment of the control obligation }\end{array}$ & District chimney sweep & commune & commune \\
\hline $\begin{array}{l}\text { Power of devices covered by the } \\
\text { control system, kW }\end{array}$ & $4-500 \mathrm{~kW}$ & 10-300 kW & do $70 \mathrm{~kW}$ \\
\hline $\begin{array}{l}\text { Types of solid fuel devices subject } \\
\text { to periodic inspection }\end{array}$ & \multicolumn{3}{|c|}{ Boilers and local space heaters } \\
\hline $\begin{array}{l}\text { Requirements during bringing to the } \\
\text { market }\end{array}$ & No & Yes & Yes \\
\hline $\begin{array}{l}\text { Emission standards in real } \\
\text { operation conditions }\end{array}$ & Yes & No & Yes \\
\hline Acceptance/initial control & $\begin{array}{l}\text { Acceptance measurement } \\
\text { for boilers; for local } \\
\text { heaters measurement } \\
\text { only in the absence of } \\
\text { documentation }\end{array}$ & No & $\begin{array}{l}\text { Acceptance measurement } \\
\text { for boilers; for local heaters, } \\
\text { measurement only in the } \\
\text { absence of documentation }\end{array}$ \\
\hline $\begin{array}{l}\text { Periodic measurement of the } \\
\text { concentration of pollutants in the } \\
\text { exhaust gas }\end{array}$ & Dust and CO for boilers & No & $\mathrm{CO}$ for boilers \\
\hline User training & Yes & Yes & Yes \\
\hline $\begin{array}{l}\text { Legal order to burn fuels specified } \\
\text { by the device manufacturer }\end{array}$ & Yes & Yes & Yes \\
\hline
\end{tabular}

introduce obligatory user training in the basics of low-emission combustion process and handling of solid fuels, including the method of storage ensuring that the required quality parameters of the fuel are maintained.

\section{Acknowledgments}

The work was carried out as part of the research and development project "Zintegrowany system wsparcia polityki i programów Ograniczenia Niskiej Emisji - ZONE" co-financed by the National Center for Research and Development under the GOSPOSTRATEG Strategic Program of scientific research and development (contract number Gospostrateg1 / 385807/4/2018 / NCBR).

\section{REFERENCES}

1. Amann M. 2018. Measures to Address Air Pollution from Small Combustion Sources. (https://ec.europa. eu/environment/air/pdf/clean_air_outlook_combustion_sources_report.pdf).

2. AWEL 2019. Amt für Abfall, Wasser, Energie und Luft im kanton Zurich; https://www.zh.ch/ de/planen-bauen/bauvorschriften/bauvorschriftenluftreinhaltung/feuerungsanlagen/feuerungskontrolle.html
3. BImSchG 1974. Gesetz zum Schutz vor schädlichen Umwelteinwirkungen durch Luftverunreinigungen, Geräusche, Erschütterungen und ähnliche Vorgänge vom 15.03.1974. (Bundes-Immissionsschutzgesetz).

4. 1.BImSchV 2010. Erste Verordnung zur Durchführung des Bundes-Immissionsschutzgesetzes über kleine und mittlere Feuerungsanlagen vom 26.01.2010.

5. BU 2018. Herausgegeben vom Bundesamt für Umwelt. Emissionsmessung bei Feuerungen für Öl, Gas und Holz. Messempfehlungen Feuerungen. 2., aktualisierte Ausgabe.. Bern, 2018.

6. DEC 2016. The Danish Ecological Council 2016. Pollution from Residential Burning. Danish experience in an international perspective. Kopenhaga.

7. DU 2016. Deutsche Umwelthilfe 2016. Residential wood burning. Environmental impact and sustainable solutions. https://www.clean-heat.eu/en/actions/info-material.html.

8. EEA 2019. European Union Emission Inventory Report 1990-2017 under the UNECE Convention on Long-range Transboundary Air Pollution (LRTAP). Kopenhaga.

9. EnEV 2017. Verordnung SR 730.02 über die Anforderungen an die Energieeffizienz serienmässig hergestellter Anlagen, Fahrzeuge und Geräte vom 1.11.2017 (Energieeffizienzverordnung).

10. GEA 2017. German Environment Agency 2017. Revised and Updated Manual on Emission Monitoring 
at Installations which do not require Official Approval within the Scope of the 1st Federal Immission Control Ordinance (1st BImSchV). Dessau-Roßlau.

11. GRAE 2010. Greek Regulatory Authority for Energy 2010. Raising the efficiency of boiler installations project. Comparison of the different guidelines for boiler inspections in participating countries. Deliverable 2.4. Comparison of the different guidelines for boiler inspections in participating countries (http://www.rae.gr/old/boileff/deliverables/D2\%20 4\%20Comparison\%20(FINAL).pdf)

12. KÜO 2009. Verordnung über die Kehrung und Überprüfung von Anlagen von 19.06.2009.

13. LVR 1985. Luftreinhalte-Verordnung SR 814.318.142.1 vom 16.12.1985.

14. NCEM 2019. The National Centre for Emissions Management Poland's Informative Inventory Report 2019. Submission under the UN ECE Convention on Long-range Transboundary Air Pollution and the Directive (EU) 2016/2284. Warszawa.

15. Notification pursuant to Article 114, paragraph 4 of the Treaty on the Functioning of the European Union - National measures which are more stringent than provisions of an EU harmonization measure. Official Journal of the European Union (2020/C 42/02)

16. SchfHwG 2008. Gesetz liber das Berufsrecht und die Versorgung im Schornsteinfegerhandwerk vom 26.11.2009 (Schornsteinfeger-Handwerksgesetz).

17. Sdělení 2019. Sdělení Ministerstva Životního Prostředí, Odboru Ochrany Ovzduší k provozování a ke kontrole spalovacích stacionárních zdrojů o jmenovitém tepelném příkonu $300 \mathrm{~kW}$ a nižším. Praha, 2019.

18. VDI 4207-2:2016. Messen von Emissionen an Kleinfeuerungsanlagen. Messen an Anlagen fur feste Brennstoffe.

19. Vyhláška č. 415/2012 Sb. o prípustné úrovni znečišt'ování a jejím zjišt'ování a o provedení některých dalších ustanovení zákona o ochraně ovzduší.

20. WHO 2015. World Health Organization Regional Office for Europe 2015. Residential heating with wood and coal: health impacts and policy options in Europe and North America.

21. Zákon č. 201/2012 Sb. ze dne 2. května 2012 o ochraně ovzduší 